\title{
Polyorchidism: A Case Report and Review of the Literature
}

\section{Poliorşidizm: Bir Olgu Sunumu ve Literatür Derlemesi}

\author{
(D) Oktay Özman1, (1) Sevim Yener22, (1) Berin Selçuk1, (1) Bülent Önal1 \\ 1 İstanbul University Cerrahpaşa Faculty of Medicine, Department of Urology, İstanbul, Turkiye \\ 2 Ümraniye Training and Research Hospital, Clinic of Pediatric Surgery, Istanbul, Turkiye
}

\begin{abstract}
Polyorchidism is defined by the presence of more than two testicles. It is a very rare anomaly. In this paper, we report a case of polyorchidism that presented as a painless scrotal mass. Undrained types require histological evaluation. Increased risk of malignancy should be taken into consideration in patients with nonscrotal supernumerary testes. We did not recommend any treatment to our patients who had scrotal supernumerary testicle and two children and decided to follow-up with scrotal ultrasound.
\end{abstract}

Keywords: Polyorchidism, Supernumerary testes, Painless scrotal mass

\section{Öz}

Poliorşidizm, ikiden fazla testisin varığı olarak tanımlanır. Çok nadir görülen bir anomalidir. Bu yazıda ağrısız skrotal kitle ile ortaya çıkan poliorşidizmli bir olgu sunuldu. Drene olmayan fazladan testisler histolojik değerlendirme gerektirir. Nonskrotal yerleşimli poliorşidik hastalarda artmış malignite riski göz önünde bulundurulmalıdır. Skrotal poliorşidizmi ve iki çocuk sahibi olan hastamıza herhangi bir tedavi önermedik ve skrotal ultrasonografi ile takip etmeye karar verdik.

Anahtar Kelimeler: Poliorşidizm, Fazladan testis, Ağrısız skrotal kitle

\section{Introduction}

Polyorchidism is defined by the presence of more than two testicles. It is also named supernumerary testicle in the literature. It is a very rare anomaly. Only about 200 cases have been reported in the literature (1). In this paper, we report a case of polyorchidism that presented as a painless scrotal mass. The management of polyorchidism is controversial.

\section{Case Presentation}

We report a 29-year-old male patient who was referred to our urology clinic with scrotal pain and had no history of trauma or any previous history of urogenital complaints. The patient reported a subacute scrotal pain that continued for two weeks. He did not report any lower urinary tract symptom. Physical examination revealed that the left and the right testicles were normal in size and position and firm in consistency. No varicocele was palpable on either side. The vasa, epididymis and penis were normal. No lymphadenopathy was detected. In the left scrotum a mass that has smaller size and same consistency with the left testiscle was palpated. It was at the inferior of the left testicle.

A scrotal grayscale ultrasonography showed a rounded structure $2.9 \mathrm{~cm}$ in diameter with clear limits, located in the left hemiscrotum adjacent to the lower pole of the left testis (Figure 1). This showed the same echogenicity, Doppler intensity and normal flow signs with the testis in color Doppler ultrasound. Testicular tumor markers profile showed lactate dehydrogenase, alpha-fetoprotein and beta-human chorionic gonadotropin within normal levels $(228 \mathrm{IU} / \mathrm{L}, 3.34 \mathrm{ng} / \mathrm{mL}$ and $0.28 \mathrm{mIU} / \mathrm{mL}$, respectively). Magnetic resonance imaging showed normal right testicle measuring approximately $5.1 \mathrm{~cm}$ in diameter and normal epididymis. Two testicles were identified on the left side with the larger one measuring approximately $4.4 \mathrm{~cm}$ in diameter, and the second one, completely independent testicle, measuring $2.8 \mathrm{~cm}$ long, was found to be adjacent to the larger one. Each testicle was seemed having its own epididymis. All the three testicles had identical signal characteristics on T1- and

Correspondence: Oktay Özman MD, İstanbul University Cerrahpaşa Faculty of Medicine, Department of Urology, İstanbul, Turkiye Phone: +90 2124143000 E-mail: ozmanoktay@ hotmail.com ORCID-ID: orcid.org/0000-0003-2499-8947

Received: 27.09.2017 Accepted: 20.11.2017

Cite this article as: Özman O, Yener S, Selçuk B, Önal B. Polyorchidism: A Case Report and Review of the Literature. 2018;5(4):211-213

${ }^{\circ}$ Copyright 2018 by the Association of Urological Surgery / Journal of Urological Surgery published by Galenos Publishing House. 
T2-weighted images. On the basis of these imaging findings, the diagnosis was polyorchidism with duplication of the left testicle (Figures 1 and 2).

All procedures performed in studies involving human participants were in accordance with the ethical standards of the institutional research committee and with the 1964 Helsinki Declaration and its later amendments or comparable ethical standards.

Informed consent was obtained from the individual participant included in the study.

\section{Discussion}

Polyorchidism is a very rare testicular anomaly. Triorchidism, which refers to the presence of three testes, is the most frequent presentation and the supernumerary testis is often located in the left side of the scrotum $(2,3)$. The most common location of the supernumerary testis is within the scrotum, superior or inferior to the ipsilateral testicle (4). In our case, the supernumerary testis was located in the left scrotum, inferior to the left testicle.

Leung classified polyorchidism into four groups based on testis embryology: 1) polyorchidism with no vas deferens or epididymis in the supernumerary testis, 2) testes sharing these two structures with the ipsilateral testicle, 3) testes with their own epididymis and sharing the vas deferens, and 4) supernumerary testes with their own annexes $(5,6)$. The patient was considered to be in the group 4. Singer et al. (7) performed a polyorchidism classification according to the localization of the extra testis and the fertility status of the patient. Our patient was not infertile and had two children (group 1A).

In a meta-analysis performed by Bergholz and Wenke (8) in 2009, it was found that the median patient age was 17 years

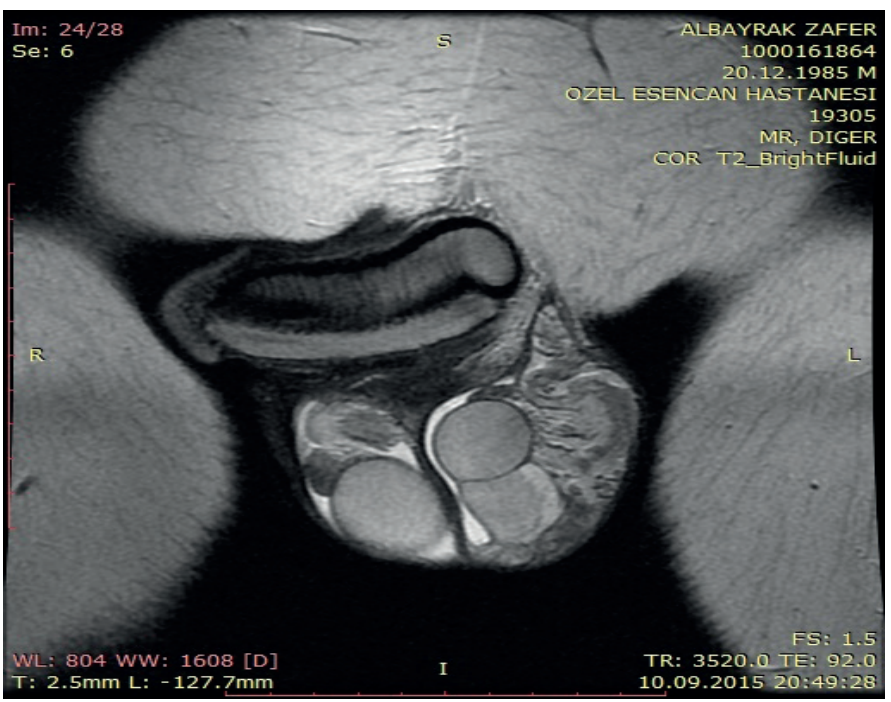

Figure 1. Right testicle and left testes in T2 weighted image and most cases of polyorchidism were confined to the left side (65\%).

The etiology is still unclear. It is thought to be accidental division of the genital ridge before $8^{\text {th }}$ week of gestation. Although there are many embryological theories in the literature, none are sufficient to explain the pathogenesis of polyorchidism alone (8).

The clinical signs and symptoms consist of scrotal pain, which may be intermittent. Many patients never experience clinical symptoms, and the diagnosis might be incidental (5). In our case, patient had a subacute scrotal pain, but it was in the right hemiscrotum and inguinal region and not associated with supernumerary testicle.

It is not clear whether or not polyorchidism is a clinical condition requiring treatment. Some authors suggest close follow-up to preserve spermatogenesis. On the other hand, excision of the supernumerary testis is recommended by some authors, taking into consideration the risk of malignancy (9). In their metaanalysis, Bergholz and Wenke (8) created a new classification for

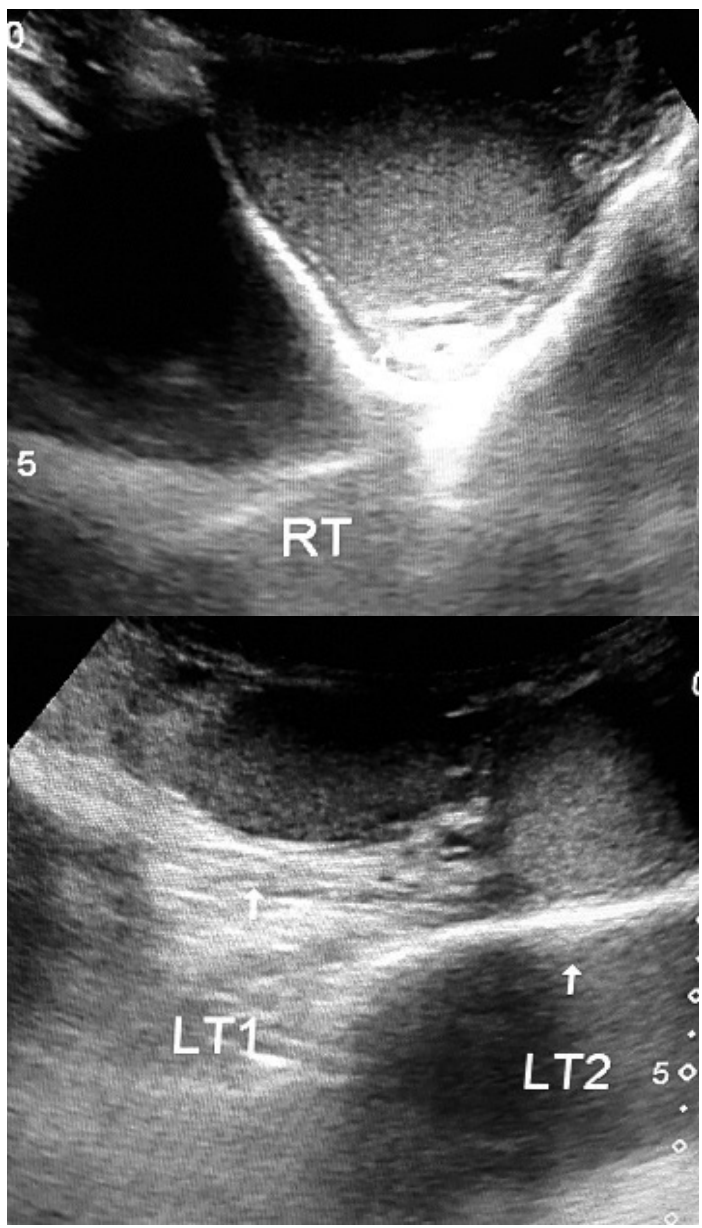

Figure 2. Single testicle in right hemiscrotum and two testes in left hemiscrotum, ultrasound images

RT: Right testicle, LT: Left testicle 
statistical analysis and management recommendations. According to this report, undrained types require histological evaluation. The most important risk factor for malignancy is the nonscrotal location of the supranumerary testis. Patients with nonscrotal supernumerary testes should be informed about the increased risk of malignancy, and removal of the undescended testis must be discussed regardless of whether it is connected to a vas deferens. The majority of supernumerary testes are located in the scrotal (66\%), inguinal (23\%) or abdominal (9\%) positions (8). Considering that the risk of malignancy was very low in our patient with scrotal placement of testis, we did not recommend any treatment and decided to follow-up with scrotal ultrasound.

\section{Ethics}

Informed Consent: Informed consent was obtained from the individual participant included in the study.

Peer-review: Externally peer-reviewed.

\section{Authorship Contributions}

Surgical and Medical Practices: 0.Ö., B.S., Concept: 0.Ö., Design: S.Y., Data Collection or Processing: B.S., Analysis or Interpretation: 0.Ö., B.Ö., Literature Search: S.Y., B.S., 0.Ö., Writing: 0.0̈., B.0̈.
Conflict of Interest: No conflict of interest was declared by the authors.

Financial Disclosure: The authors declared that this study received no financial support.

\section{References}

1. Artul S, Habib G. Polyorchidism: two case reports and a review of the literature. J Med Case Rep 2014;8:464.

2. Chintamani J, Nyapathy V, Chauhan A, Krishnamurthy U. Supernumerary Testis. J Radiol Case Rep 2009;3:29-32.

3. Woodward PJ, Schwab CM, Sesterhenn IA. From the Archives of the AFIP: extratesticular scrotal masses: radiologic-pathologic correlation. Radiographics 2003;23:215-240.

4. Wolf B, Youngson GG. Polyorchidism. Pediatr Surg Int 1998;13:65-66.

5. Avargues A, Rogel R, Broseta E, Luján S, Betancourt JA, Morales G, Boronat F. Polyorchidism: the case in a young male and review of the literature. Asian J Androl 2015;17:511-512.

6. Leung AK. Polyorchidism. Am Fam Physician 1988;38:153-156.

7. Singer $B R$, Donaldson JG, Jackson DS. Polyorchidism: Functional classification and management strategy. Urology 1992;39:384-388.

8. Bergholz R, Wenke K. Polyorchidism: a meta-analysis. J Urol 2009;182:24222427.

9. Nayak SP, Sreejayan MP. Management of supernumerary testis in an adult: case report and review. Andrologia 2011;43:149-152. 